ROYAL INSTITUTE OF ChE YISTRY, LONDON AND S.E. CODNTIES SECTION (joint meeting with the W WLWYN GARDEN CITY SCIENTISTS' Club, at The Cherry Tree, Welwyn Garden City), at

INSTITUTION OF ELEOTRICAL ENGINEERS, CAMBBRIDGE RADIO GROUP (at the Cavendish Laboratory, Cambridge), at 8.15 p.m.-Prof. D. $R$. Hartree: "Electronic Calculating Machines".

\section{Wednesday, March 9}

INSTITUTE OF FURL, NORTH-WESTERN SECTION (joint meeting with the NATIONAL SMOKE ABATEMENT SOCIETY, at the Engineers' Club, Albert Square, Manchester), at 2 p.m.-Mr. P. D. Kirkman: "The Efficient Use of Fuel".

ROYAL SOCIETY OF ARTS (at John Adam Street, Adelphi, London, W.C.2), at 2.30 p.m.- Sir John Forsdyke: "The Functions of a National Museum" (Trueman Wood Lecture). (Further Lectures in the series on Museums will be given on March 23 (Mr. Trenchard "Mus : The Provincial Museum"), March 30 (Mr. Edgar Kaufmann "The Local Museum"), April 27 (Dr. Iorwerth C. Peate : "The Folk Museum"), May 11 (Mr. Elias Svedberg: "Museum Display"), and on Maveum 25 (Dr. D. A. Allan: "Museums and Education").)

LINNEAN SociETY OF LoNDON (at the British Museum (Natural History), Cromwell Road, London, S.W.;), at 3 p.m.-Demonstration: "Zoological Taxonomy after 1758".

Society of Public analysts and other analytical Chemists (at the Royal Society, Burlington House, Piccadilly, London, W.1), at 3.30 p.m.-Annual General Meeting.

Socigty of Chemical Industry, Miorobiological Panel of the FooD GRoup (at the Medical Society of London, 11 Chandos Street, Cavendish Square, London, W.1), at 6.15 p.m.- Annual General Problems in the Production of Pure Water".

Solentifio Film Association (in the Lecture Theatre, Wellcome Foundation, 183 Euston Road, London, N.W.1), at 7 p.m.-Miss F. Anthony: "The Organisation of a Research Film Unit".

INSTITUTION OF THE RUBBER INDUSTRY, SOUTHERN SECTION (at the Polygon Hotel, Southampton), at 7.15 p.m.-Mr. H. J. Lanning "Neoprene".

SOOIETY OF INSTRUMENT TECHNOLOGY, NORTH-WEST SEOTION (at the College of Technology, Manchester), at 7.30 p.m.-Mr. G. A. R oster : 'Som of the Regularity of Cotton Yarns and Rovings".

\section{Thursday, March 10}

Royal Society (at Burlington House, Piccadilly, London, W.1), at 4.30 p.m. - Sir Charles Harington, F.R.S.: "National Institute for Medical Research".

UNIVERstry of London (in the Physiology Theatre, University College, Gower Street, London, W.C.1), at 4.45 p.m.-Dr. C. E. Dent "The Development and Application of Paper Chromatography"." (Further Lecture on March 17.)

LINNEAN SOCIETY OF LONDON (joint meeting with the SYSTEMATIOS Association, at Burlington House, Piccadilly, London, W.1), at 5 p.m.-Discussion on " Cytolo
opened by Dr. W. B. Turrill).

Royal Statistical Sociery, Research Section (at the London School of Hygiene and Tropical Medicine, Keppel Street, London,
W.C.1), at 5.15 p.m.-Mr. G. A. Barnard : "Statistical Inference". ILluminating Engineering Society, Manchester Centre (in the Reynolds Hall, College of 'Technology, 'Manchester), at 6 p.m.-Mr.
W. E. Harper and Mr. H. P. Walker: "Acrylic Plastics in Lighting". W. E. Harper and Mr. H. P. Walker: "Acrylic Plastics in Lighting". STRUCTURAL FNGINEERS, 11 Upper Belgrave Street, London, S.W.1) at 6 p.m. - Mr. J., T. Phillips and Mr. F. J. Daniels: "Welded Steel Framed Buildings".

Sociery of Chemical Industry (joint meeting of the NotTrNgham SBCTION and the FINE CHEMrICALS Group, at the Gas Company's Show Room, Parliament Street, Nottingham), at 6.30 p.m.-Mr. J. C. Chemistry to the Study of certain Biologically Active Compounds".

BRitish Association of ChEMISTs (at Gas Industries House, 1 Grosvenor Place, London, S.W.1), at 7 p.m.-Dr. Joseph Needham, F.R.S.: "The Work of U.N.E.S.C.O."."

UNIVERSITY OF LONDON (at Wye College, Wye, Kent).-- Sir John Kussell, F.R.S.: "Agricultural Research in the 20th Century" (Fellowship Lecture).*

\section{Friday, March II}

ROYAL AstronomionI Societr (at Burlington House, Piccadilly, London, W.1), at 4.30 p.m.- Scientific Papers.

Physical Societr (in the Science Museum Exhibition Road, London, S.W.7), at 5 p.m. - Scientific Papers. (Members of the Colour Group are invited.)

Society of Publid analysts and other analytical Chemists, PHYSICAL METhoDs GROUP (in the Chemistry Lecture Theatre, Imperial College of Science and Technology, Imperial Institute Road, London, S.W.7), at 5.30 p.m.- -Discussion on "Polarographic Analysis". UNIVERSITY OF LONDON (n) Royal "Tensington, London, S.W.7), at 5.30 p.m.-Prof. F. T. Brooks :

INSTTTUTION OF EleCtrical ENGINEERS, EDUCATION DISCUSSION Cirole (at Savoy Place, Victoria Embankment, London, W.C.2), at 6 p.m.-Discussion on "The Application of Flux Meters to Experiments on Flectric Machines" (to be opened by Prof. E. B. Moullin).

NORTH-EAST COAST INSTITUTION OF ENGINEERS AND SHIPBUILDERS (at the Mining Institute, Newcastle-upon-Tyne), at 6.15 p.m.-Mr. R. W. L. Gawn: "Cavitation of Screw Propellers".
INSTITUTION OF STRUCTURAI, ENGINEFRS, LANCASHIRE AND CHESHIRE BRANCH (at the College of Technology, Manchester), at 7 p.m.-Mr. G. R. Hinks: "Building the Central Library and Town Saturday, March 12

INSTTTUTION OF CHEMICAL ENGINERRS, NORTH-W RSTERN BRANCH (in the Reynolds Hall, College of Technology, Manchester), at 3 p.m."-

\section{APPOINTMENTS VACANT}

APPLICATIONS are invited for the following appointments on or before the dates mentioned:

AssistanT AGRICULTURAL Economist in the Department of AgTiculture-The Registrar, The University, Leeds 2 (March 10)

SENIOR SCIENTIFIC OFFICER (with a degree in science with firstclass honours in botany) and a SENIOR EXPERIMENTAL OFFICER (with at least the H.S C. in a science subject or equivalent qualification an

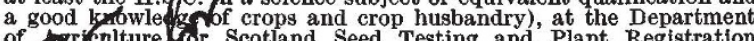
of pricpltur for Scotland Seed Testing and Plant Registration Serv co dofm ission, Scientific Branch, 27 Grosvenor Square, London, W.1 quoting No. 2434 (March 10)

ASSISTANT EXPERIMENTAL OFFICERS (3, temporary), Food Infestation Control, Department of Agriculture for Scotland--The Secretary, Ministry of Labour and National Service, Technical and Scientific G.536/48 (March 10)

DRPUTy STATISTICAL OFFICER in the Statistical Section of the Town Clerk's Department-The Town Clerk, Room 30B, Council House, Birmingham 1, endorsed 'Deputy Statistical Officer' (March 11).

LeOTURER IN Chemical ENGINaERING-The Clerk to the Governing Body, Battersea Polytechnic, Battersea, London, S.W.11 (March 12). RESEARCH MANAGER-The Director, Motor Industry Research Association, Great West Road, Brentford, Middx. (March 12).

LEOTURER (Grade III) IN CHEMISTRY, with special interest in physical and inorganic chemistry-The Registrar, Queen Mary College, Mile End Road, London, E.1 (March 14).

JUNIOR ASSISTANT PHYSICIST in the Physics Department-The Secretary, Bristol Royal Hospital, General Hospital Branch, Guines Street, Bristol 1 (March 15)

GEOLOGICAL AND TOPOGRAPHICAL DRAUGHTSMEN in the Department of the Geological Survey of Southern Rhodesia-The Secretary, Rhodesia House, 429 Strand, London, W.C.2 (March 15).

LECTURmRs (2, Grade II) IN MINING-The Secretary, The University, Birmingham 3 (March 19).

RRADERSHP IN THForetical Physics at Queen Mary CollegeThe Academic Registrar, University of London, Senate House, Lon, W.C.1 (March 21) -The Education Officer (H.1/2), County Hall, Westminster Bridge, London, S.E.1 (April 1).

Visiting Professor of Plant Physiology at the Faculty of Science,

Farouk I University, Alexandria-The Director, Egyptia

SENIOR TECHNICIAN with histological training for laboratory principally engaged in endocrinological research-Professor of Anatomy Medical School, Edgbaston, Birmingham 15

LABORATORY TECHNICLANS-The Regional Blood Transfusion Officer, Bridle Path, York Road, Seacroft, Leeds

SENIOR TECHNICLAN in the Department of Materia Medica-The Administrative Officer, Medical School, Dundee.

LABORATORY ASSISTANT to help in sorting and mounting entomological material-The Secretary, Department of Entomology and Parasitology, School of Tropical Medicine, Liverpool 1.

PHYSICIST or ENGINEER to develop various special components of the cyclotron, and a VACOUM ENGINEER-The Director, Radiotherapeutic Research Unit, Hammersmith Hospital, Dueane Road, London, W.12, endorsed 'Cyclotron'.

EXPERIMENTAL OFFICERS (2) to assist in studies of Bee behaviourThe Secretary, Rothamsted Experimental Station, Harpenden, Herts RESEARCH PHYSICIST for fundamental research on Atmospheri Physics-Dr. G. B. B. M. Sutherland, Pembroke College, Cambridge TEchnicis (Grade III) as second Lecture Theatre Assistant in the Department of Physics (Ref. Physics/2), and a TrohnoLAN (Grade IV) in the Department of Geology (Ref. Geology/2)-The the apry, University

ENTOMOLOGISTS (2) in the Research Division of the Department of Agriculture and Forests, Sudan Government-The Sudan Agent in London, Wellington House, Buckingham Gate, London, S.W.1, endorsed 'Agricultural Entomologist'.

INSPECTOR (Plant Protection) IN THE RESEARCH DIVISION of the Department of Agriculture and Forests, Sudan Government-The Sudan Agent in London, Wellington House, Buckingham Gate, London, S.W.1, endorsed 'Plant Protection'.

LECTURER or ASSISTANT LECTURER IN MATHEMATICS-The Registrar. LECTURER or ASSISTANT L
University College, Exeter.

SURvEYoRs (experienced and qualifled) in the Survey Department of Hong Kong, Malaya, Nigeria, the Gold Coast and TanganyikaThe Director of Recruitment, Colonial Service, Sanctuary Buildings, Great Smith Street, London, S.W.1.

PHYSIOIST, a CHEMIST, and an ENGINEER, for a new laboratory at Galashiels-The Secretary, Wool Industries Research Association, Torridon, Leeds 6 .

FIELD ZOOLOGIST in the Veterinary Department, Kenya, for Tsetse Fly survey and control-The Director of Recruitment, Colonial Service, Colonial Office, Sanctuary Buildings, Great Smith Street London, S.W.1.

LECTURER IN GENERAL SCIENOE with particular application to foodstuffs, and a LEOTURER IN FOODSTUFFS with experience in nutri-
tion and microbiology-The Principal, Borough Polytechnic, Borough Road, London, S.E.1. 